Research

\title{
Transforming growth factor-beta inhibits aromatase gene transcription in human trophoblast cells via the Smad2 signaling pathway Hong Zhou ${ }^{1,2}$, Guodong Fu' ${ }^{1}$, Hui $\mathrm{Yu}^{1}$ and Chun Peng*1
}

Address: ${ }^{1}$ Department of Biology, York University, Toronto, Ontario, M3J 1P3, Canada and ${ }^{2}$ School of Life Science and Technology, University of Electronic Science and Technology of China, Chengdu, PR China

Email: Hong Zhou - zhouhongzh@uestc.edu.cn; Guodong Fu - guodong@yorku.ca; Hui Yu - lifengyuhui@hotmail.com; Chun Peng* - cpeng@yorku.ca

* Corresponding author

Published: 9 December 2009

Reproductive Biology and Endocrinology 2009, 7:146 doi:10.1186/1477-7827-7-146

This article is available from: http://www.rbej.com/content/7////46

(C) 2009 Zhou et al; licensee BioMed Central Ltd.

This is an Open Access article distributed under the terms of the Creative Commons Attribution License (http://creativecommons.org/licenses/by/2.0), which permits unrestricted use, distribution, and reproduction in any medium, provided the original work is properly cited.
Received: 26 October 2009

Accepted: 9 December 2009

\begin{abstract}
Background: Transforming growth factor-beta (TGF-beta) is known to exert multiple regulatory functions in the human placenta, including inhibition of estrodial production. We have previously reported that TGF-betal decreased aromatase mRNA levels in human trophoblast cells. The objective of this study was to investigate the molecular mechanisms underlying the regulatory effect of TGF-betal on aromatase expression.

Methods: To determine if TGF-beta regulates aromatase gene transcription, several reporter constructs containing different lengths of the placental specific promoter of the human aromatase gene were generated. JEG-3 cells were transiently transfected with a promoter construct and treated with or without TGF-betal. The promoter activity was measured by luciferase assays. To examine the downstream signaling molecule mediating the effect of TGF-beta on aromatase transcription, cells were transiently transfected with dominant negative mutants of TGF-beta type II (TbetaRII) and type I receptor (ALK5) receptors before TGF-beta treatment. Smad2 activation was assessed by measuring phophorylated Smad2 protein levels in cytosolic and nuclear fractions. Smad2 expression was silenced using a siRNA expression construct. Finally, aromatase mRNA half-life was determined by treating cells with actinomycin $D$ together with TGF-betal and measuring aromatase mRNA levels at various time points after treatment.
\end{abstract}

Results and Discussion: TGF-betal inhibited the aromatase promoter activity in a time- and dosedependent manner. Deletion analysis suggests that the TGF- $\beta$ I response element resides between -422 and -117 nucleotides upstream from the transcription start site where a Smad binding element was found. The inhibitory effect of TGF-betal was blocked by dominant negative mutants of TbetaRIl and ALK5. TGFbetal treatment induced Smad2 phosphorylation and translocation into the nucleus. On the other hand, knockdown of Smad2 expression reversed the inhibitory effect of TGF-betal on aroamtase transcription. Furthermore, TGF-betal accelerated the degradation of aromatase mRNA.

Conclusion: Our results demonstrate that TGF-betal exerts regulatory effects on aromatase gene at both transcriptional and post-transcriptional levels. The transcriptional regulation of aromatase gene by TGF-betal is mediated by the canonical TGF-beta pathway involving TbetaRII, ALK5 and Smad2. These findings further support the role of TGF-betal in regulating human placental functions and pregnancy. 


\section{Background}

Transforming growth factor- $\beta$ (TGF- $\beta$ ) regulates many physiological processes, including reproduction [1-3]. During human pregnancy, TGF- $\beta$ regulates placental trophoblast cell proliferation and differentiation, as well as hormone production $[2,4-8]$. TGF- $\beta$ signaling is initiated at the cell surface by interaction of the ligand with receptor complexes that are composed of type I and type II receptor serine/threonine protein kinases [9]. In general, TGF- $\beta$ interacts with its specific type II receptor (T $\beta$ RII) and a type I receptor referred to as activin receptor-like kinase 5 (ALK5) [9-11]. ALK5 activates Smad2 and Smad3 through phosphorylation [9-11]. Following activation, Smad2 and Smad3 form complexes with a common Smad (Smad4) and enter the nucleus where they interact with other transcription factors, coactivators and corepressors to regulate gene transcription [12-14].

Aromatase, encoded by the CYP19 gene, is a key enzyme involved in estrogen biosynthesis [15]. The CYP19 gene has 9 coding exons (exon II-X) and the $5^{\prime}$ untranslated region is encoded by exon I which is alternatively used by different tissues [15]. The gene uses multiple promoters in a tissue-specific manner, resulting in a tissue-specific regulation of the aromatase activity [16]. Although aromatase transcripts in different tissues have their own unique Exon I, they are spliced onto a common site upstream of the translation initiation site in exon II, thus resulting in the identical aromatase protein [17]. TGF- $\beta$ has been found to regulate human aromatase expression in a tissue-specific manner. It decreased aromatase mRNA levels and activity in trophoblast cells [18], fetal hepatocytes [19], adipose stromal cells $[5,20]$ and skin fibroflasts [21]. However, in osteoblast-like cells and THP-1 cells, TGF- $\beta 1$ has been found to stimulate aromatase gene transcription [22]. In a leukaemic cell line FLG29.1, TGF- $\beta 1$ stimulated aromatase expression and enzyme activity [23].

We have previously reported that TGF- $\beta 1$ decreased aromatase mRNA levels in trophoblast cells [5]. To determine the mechanisms underlying this action, we examined the $5^{\prime}$ flanking region of the placental specific exon I.1 of the aromatase gene and identified several Smad binding elements. We therefore proposed that TGF- $\beta$ acts through the Smad pathway to inhibit aromatase transcription. Since a decrease in mRNA level may also be resulted from a decrease in mRNA stability, we also investigated whether TGF- $\beta 1$ regulates aromatase mRNA stability.

\section{Methods \\ Cell culture}

JEG-3 cells were purchased from American Type Culture Collection (Rockville, MD). The cells were cultured in minimal essential medium (MEM, Canadian Life Tech- nologies, Inc.) containing $10 \%$ fetal bovine serum (FBS, Sigma-Aldrich Canada Ltd, Oakville, ON) and antibiotics (100 IU/m penicillin, and $100 \mu \mathrm{g} / \mathrm{ml}$ streptomycin, purchased from Invitrogen Canada Inc. Burlington, $\mathrm{ON}$ ).

\section{Expression constructs}

Expression constructs for constitutively active and dominant negative ALK5, and dominant negative T $\beta$ RII were kindly provided by Dr. L. Attisano (Univ of Toronto). Luciferase reporter constructs were generated using pGL3 basic luciferase reporter vector (Promega, Madison, WI). To obtain DNA fragments containing different lengths of the exon I.1 5 ' flanking sequence $(+120$ to $-2538,+120$ to $-1333,+120$ to $-714,+120$ to -422 , and +120 to -117 ), PCR was performed using genomic DNA extracted from JEG-3 cells as the template. All PCRs were carried out for 30 cycles using a common antisense primer, 5'-AGATTAAGAGATACATACGCG-3', and a specific sense primers (5'CCCGGTACCCCAGATGATCTTTCCCAGGAA-3' for Arom -2538 construct; 5'-CTGTGGAACCATGAGC CA ATT-3' for Arom-1333; 5'-GCATTGGAGATACGGAAGTAA-3' for Arom -714; 5'-TGTAGAA CAATG TG GT GTGTG-3' for Arom-422; and 5'-AGACCTTGCTGAGATTAGATC-3' for Arom-117). The resulting DNA fragments were first cloned into pCRII vector using a TOPO cloning kit (Invitrogen). The inserts were then cut out from pCRII vector using KpnI and Xhol (for Arom -1333, Arom -714 bp, Arom -422 bp and Arom -117 bp) and KpnI and NheI (for Arom -2541) respectively, and then subcloned into the pGL3-basic vector. All promoter constructs were fully sequenced to verify their identities.

\section{Transient transfection and luciferase assay}

JEG-3 cells were seeded into 6-well plates at a density of 2 $\times 10^{5}$ cells/well and incubated in MEM containing 10\%FBS for 24 hours. Transient transfection was carried out using a $25 \mathrm{kDa}$ polyethylenimine (PEI, SigmaAldrich) as previously described [24]. After transfection for $4 \mathrm{~h}$, the medium was replaced with MEM supplied with $10 \%$ FBS and cells were allowed to be recovered for different lengths of time. After treatment with TGF- $\beta 1$, cells were then lysed in $250 \mu \mathrm{l}$ of lysis buffer $(20 \mathrm{mM}$ Tris PH 7.4/0.1\% TritonX-100). The supernatant was collected for both luciferase and $\beta$-gal assays. To determine the luciferase activity, $100 \mu \mathrm{l}$ of luciferase substrate (Promega) was added to $30 \mu \mathrm{l}$ supernatant and the total light emission during the initial 10 seconds of the reaction was measured using a luminometer. For $\beta$-gal assay, $30 \mu \mathrm{l}$ of supernatant was added into $270 \mu \mathrm{l}$ of reaction mixture (1 $\mathrm{ml}$ contains $244 \mu \mathrm{l}$ of $4 \mathrm{mg} / \mathrm{ml}$ of 2-Nitrophenyl- $\beta$-DGalactopyranoside (ONPG), $2.22 \mu \mathrm{l}$ of $0.5 \mathrm{M} \mathrm{MgSO}_{4}$, $3.89 \mu \mathrm{l}$ of $\beta$-mercaptoethanol, $186.2 \mu \mathrm{l}$ of $0.4 \mathrm{M}$ sodium phosphate buffer, and $563.9 \mu \mathrm{l}$ of water, and all chemicals were purchased from Sigma-Aldrich), mixed well and incubated at $37^{\circ} \mathrm{C}$ for $30 \mathrm{~min}$ or until a yellow color 
change was detectable. The reaction was then terminated by the addition of $500 \mu \mathrm{l}$ of $1 \mathrm{M} \mathrm{Na}_{2} \mathrm{CO}_{3}$ and absorbance at $410 \mathrm{~nm}$ was measured using a spectrophotomer. The luciferase assay data were normalized by $\beta$-gal activity and expressed as relative luciferase activity.

\section{Treatment with TGF- I}

Cells were plated into 6-well plates at the density of $2 \times$ $10^{5} \mathrm{cells} /$ well and allowed to grow overnight. To determine the effect of TGF- $\beta 1$ on aromatase gene transcription, cells were either treated with different concentrations of TGF- $\beta 1$ for 2 hours or $1 \mathrm{ng} / \mathrm{ml}$ of TGF$\beta 1$ for different time periods ( $2 \mathrm{~h}, 6 \mathrm{~h}, 12 \mathrm{~h}$ and $24 \mathrm{~h}$ ).

\section{Silencing of Smad2 expression}

Smad2 expression was knockdown using its siRNA. The published Smad2 siRNA sequence (UCUUUGUGCAGAGCCCCAAtt [25]) was cloned into the pSuper vector (Oligoengine, Seattle, WA), and JEG-3 cells were transiently transfected with either the control pSuper vector or the siRNA for Smad2 for $4 \mathrm{~h}$. After recovering for 12, 24, 48 and $72 \mathrm{~h}$, protein extract was prepared from cells and Western blotting was performed using an antibody against human Smad2 (Cell Signalling). To determine the effect of Smad 2 silencing on TGF- $\beta$ action, cells were first transfected with the control or siRNA plasmid for $4 \mathrm{~h}$ and recovered for $24 \mathrm{~h}$ before being treated with TGF- $\beta 1$ ( $1 \mathrm{ng} /$ $\mathrm{ml})$ for $6 \mathrm{~h}$.

\section{Protein extraction and Western blot analysis}

The whole cell extraction was carried out as described previously with some modification [26]. Briefly, JEG-3 cells were plated using a density of $6 \times 10^{5}$ cells/dish in $60-\mathrm{mm}$ dishes and incubated overnight. Following treatment with $1 \mathrm{ng} / \mathrm{ml} \mathrm{TGF}-\beta 1$ for $30 \mathrm{~min}$, the cells were lysed in lysis buffer (50 mM Tris-HCl, $150 \mathrm{mM} \mathrm{NaCl}, 1 \%$ Triton X-100, $0.5 \%$ deoxycholate, and $1 \%$ SDS) containing $1 \mathrm{mM}$ dithiothreitol, $1 \mathrm{mM} \mathrm{Na}_{3} \mathrm{VO}_{4}, 5 \mathrm{mM} \mathrm{NaF}, 100 \mathrm{mM}$ EDTA, 10 $\mathrm{mg} / \mathrm{ml}$ aprotinin, and $100 \mathrm{mM}$ phenylmethysulfonyl fluoride. Nuclear proteins and cytoplasm proteins were extracted using Nuclear Extraction Kit (Panomics) following the manufacturer's protocols and stored at $-20^{\circ} \mathrm{C}$ until Western blot analysis. Proteins $(40 \mu \mathrm{g})$ were separated by SDS-polyacrylamide gel electrophoresis in $12 \%$ gels. The proteins were transferred electrophoretically onto polyvinylidene difluoride membranes (Immobilon-P, Millipore Corp., Bedford, MA). After blocking with 5\% milk in TBS$\mathrm{T}$, the membranes were incubated with rabbit anti-human phospho-Smad2 (1:1000 dilution, Cell Signaling) or phosphor-Smad3 (1:1000 dilution, Cell Signaling), or mouse anti-human actin (1:1000 dilution, Sigma) antibodies at $4{ }^{\circ} \mathrm{C}$ overnight. The membranes were subsequently probed with horseradish peroxidase-conjugated anti-rabbit or anti-mouse (1:5000 dilution, Amersham) at room temperature for $1 \mathrm{~h}$. Signals were detected using a
ECL-Plus kit (Amersham) according to the instructions of the manufacturer.

\section{Aromatase mRNA stability assays}

To study the effect of TGF- $\beta 1$ on aromatase mRNA stability, JEG-3 cells were seeded at a density of $1 \times 10^{6}$ cells/60 $\mathrm{mm}$ dish. $24 \mathrm{~h}$ after plating, cells were treated with $2 \mu \mathrm{g} /$ $\mathrm{ml}$ actinomycin $\mathrm{D}$ (Sigma), either alone or in the presence of $1 \mathrm{ng} / \mathrm{ml}$ of TGF- $\beta 1$, in serum free medium. The cells were then harvested at time 0 (pretreatment) and 6, 12, 24,36 and $48 \mathrm{~h}$ after treatment with TGF- $\beta 1$. Total RNA was then extracted using Trizol reagent (Invitrogen) following the manufacturer's recommended protocol and reversed transcribed into cDNA as previously described [5]. Aromatase mRNA levels were determined using RTPCR. GAPDH was used as internal control to normalize the aromatase mRNA level. The GAPDH sense primer was 5'-AAGGTCATCCCTGAGCTGAAC, and antisense primer was 5'-CGCCTGCTTCACCACCTTCTA. Primers used in aromatase PCR were sense: 5'-GCTGCAGTGCATCGGTATGCA-3', and antisense: 5'-ACTCGAGTCTGTGCATCCTTC-3'. Validation assays were performed to determine the proper cycle number and the numbers chosen for aromatase ( 32 cycles) and GAPDH ( 22 cycles) are in the linear range of amplification.

\section{Statistical analysis}

All transfection assays were performed in triplicate and repeated at least three times. The relative luciferase activity shown in figures was the Mean \pm SEM for triplicate wells from one representative experiment. Statistical analysis was done with one-way ANOOVA, followed by a StudentNewman-Keul's multiple comparison tests using Graph Pad InStat software (Graph Pad Inc., San Diego, CA). For comparison between two groups, Student's $t$ test was used. Differences were considered statistically significant at $\mathrm{P}<0.05$.

\section{Results}

\section{TGF- $\beta$ I inhibits aromatase gene transcription}

Examination of the major promoter region that directs placenta-specific expression of the aromatase gene reveals the presence of four Smad binding elements (SBE) [27], CAGAC, located at +93 to $+97,-114$ to $-118,-118$ to -122 , and -1186 to -1182 (Fig. 1A). This suggests that the TGF- $\beta$ family may regulate aromatase transcription via the Smad pathway. Since TGF- $\beta 1$ decreased aromatase mRNA [5], we therefore tested its effect on aromatase gene transcription. Five promoter constructs containing different lengths of the 5' flanking sequence of the exon I.1, designated as Arom -2538, Arom -1333, Arom -714, Arom 422, and Arom -117, were made and used to test the effect of TGF- $\beta 1$. JEG-3 cells were transiently transfected with a luciferase construct and then treated with or without TGF$\beta 1$. TGF- $\beta 1$ inhibited promoter activities in Arom -2538, 
A.

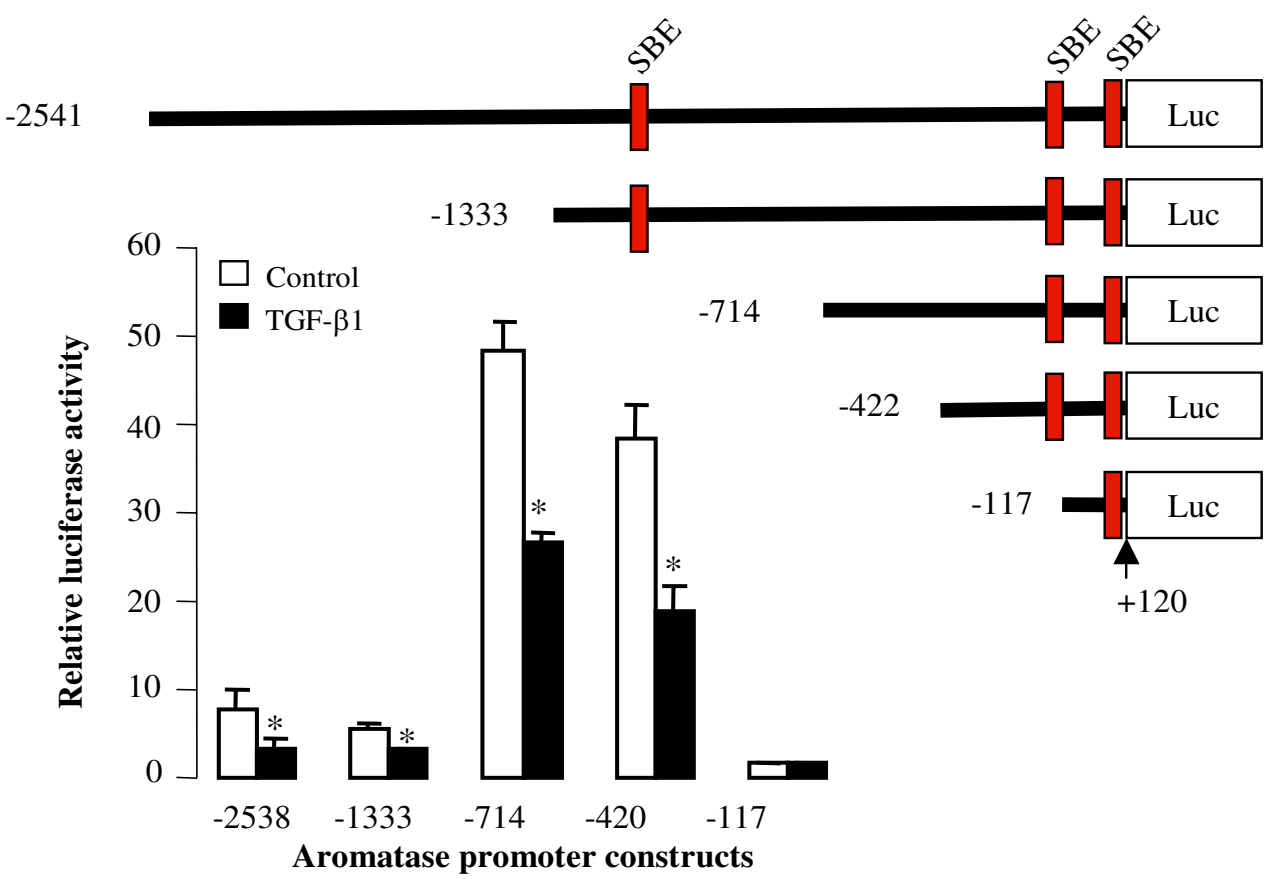

B.

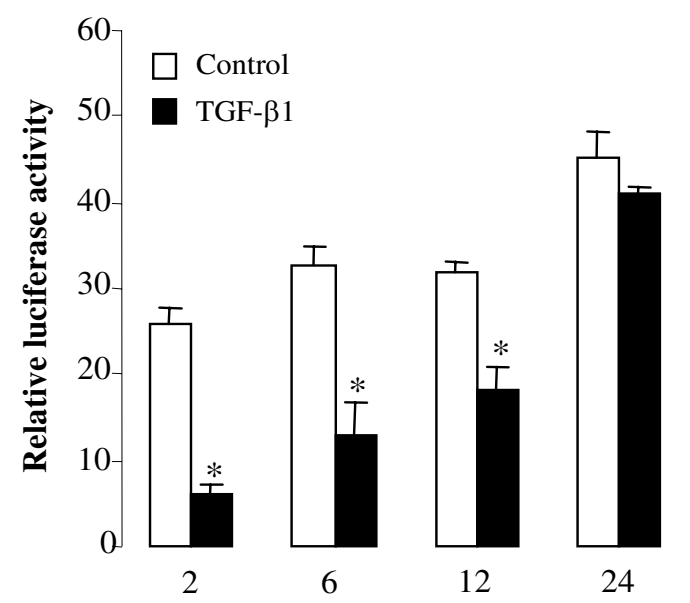

Treatment time (h)
C.

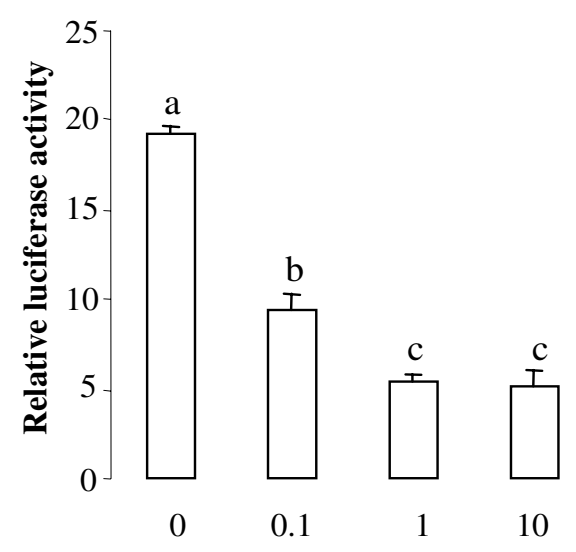

[TGF- $\beta 1], \mathbf{n g} / \mathrm{ml}$

Figure I

Placental aromatase promoter constructs and the effect of TGF- $\beta$ I on promoter activities. A) Various lengths (2538 to -1 I7) of the $5^{\prime}$ flanking region of the placental specific exon I were cloned into a luciferase reporter construct pGL3 basic. Smad binding elements (SBE) are shown at the red box region. JEG-3 cells cultured in 6-well plates were transfected with these luciferase constructs $(\mathrm{I} \mu \mathrm{g})$ and then treated with or without TGF- $\beta \mathrm{I}(\mathrm{I} \mathrm{ng} / \mathrm{ml})$ for $6 \mathrm{~h}$. B) Cells were transfected with Arom $-7 / 4$ construct and then treated with TGF- $\beta \mathrm{I}(\mathrm{I} \mathrm{ng} / \mathrm{ml})$ for the duration as indicated. C) Cells were transfected with Arom -7/4 - and then treated with different concentrations of TGF- $\beta$ I for $6 \mathrm{~h}$. In these experiments, a $\beta$-galactosidase expression vector $(0.5 \mu \mathrm{g})$ was co-transfected into cells for normalizing transfection efficiency. Relative luciferase activity was calculated as the ratio of luciferase/ $\beta$-gal. Data are mean \pm SEM of three replicates from one experiment. The experiment has been repeated twice with similar results. *, $\mathrm{P}<0.05$ verse empty vector control. 
Arom -1333, Arom -714, and Arom -422 constructs. Deletion between -422 and -117 abolished the basal promoter activity as well as the inhibitory effect of TGF- $\beta 1$ (Fig. 1A).

The dose-dependent and time-course effects of TGF- $\beta 1$ were subsequently tested using promoter construct Arom -714. A significant decrease in aromatase promoter activity was observed at 2 to $12 \mathrm{~h}$ after TGF- $\beta 1$ treatment (Fig. $1 \mathrm{~B})$. At $6 \mathrm{~h}$ after treatment, all doses of TGF- $\beta 1$ ( 0.1 to 10 $\mathrm{ng} / \mathrm{ml}$ ) significantly inhibited luciferase activity; with a maximal effective dose observed at $1 \mathrm{ng} / \mathrm{ml}$ (Fig. 1C).

\section{TGF- $\beta$ I acts through T $\beta R I I, A L K 5$, and Smad2 to regulate aromatase gene transcription}

To confirm that TGF- $\beta 1$ acts through its specific receptors and the Smad pathway to regulate aromatase gene transcription, several experiments were performed. First, cells were transfected with dominant negative mutant of T $\beta$ RII, or its vector control (pCMV5) and then treated with or without $1 \mathrm{ng} / \mathrm{ml}$ TGF- $\beta 1$. As shown in Fig. $2 \mathrm{~A}$, TGF- $\beta 1$ treatment decreased luciferase activity in the pCMV5transfected cells, but not in the dominant negative T $\beta$ RIItransfected cells, indicating that dominant negative T $\beta$ RII reversed the inhibitory effect of TGF- $\beta 1$ on aromatase gene transcription. Second, the involvement of ALK5 in TGF- $\beta 1$-regulated aromatase transcription was examined using both constitutive active and dominant negative mutants. Transfection of the constitutively active ALK5 inhibited the aromatase promoter activity to a similar extend as TGF- $\beta 1$ treatment (Fig. $2 \mathrm{~B}$ ). On the other hand, overexpression of dominant negative ALK5 completely blocked the effect of TGF- $\beta 1$ on aromatase promoter activity (Fig. 2B).

We subsequently investigated if the Smad pathway is involved in the TGF- $\beta 1$-regulated aromatase transcription. First, protein samples were extracted from cells at $30 \mathrm{~min}$ after TGF- $\beta 1$ treatment and immunoblotting was performed. TGF- $\beta 1$ strongly induced Smad2 phosphorylation (Fig. 3A). Consistent with our previous report that Smad3 expression level is very low in JEG3 cells [28], pSmad3 was only weakly detected in the TGF- $\beta 1$-treated cells (Fig. 3A). To further confirm the activation of Smad2, protein samples were prepared from cytoplasmic and nuclear fractions of the control and TGF- $\beta 1$-treated cells. Treatment with TGF- $\beta 1$ resulted in strong accumulation of phosphorylated Smad2 in the nucleus (Fig. 3B). To directly examine the role of endogenous Smad2, we generated a siRNA construct to silence Smad2 expression. Compared to the vector control, transfection with siSmad 2 construct resulted in a decrease in Smad 2 protein levels at 24, 48 and $72 \mathrm{~h}$ after transfection (Fig. 3C). When cells were transfected with siSmad 2 construct before TGF$\beta 1$ treatment, we found that knockdown of Smad2 com-
A.

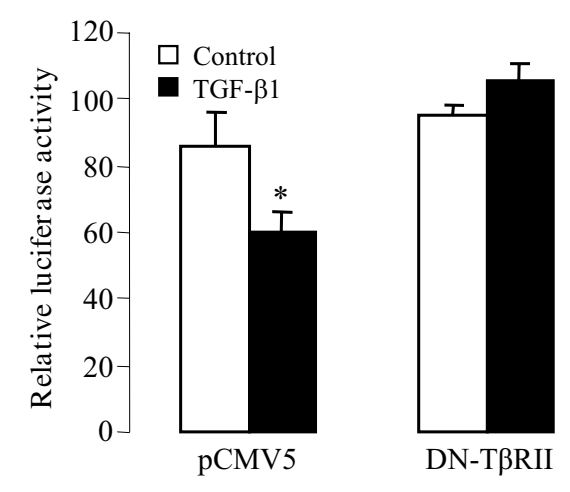

B.

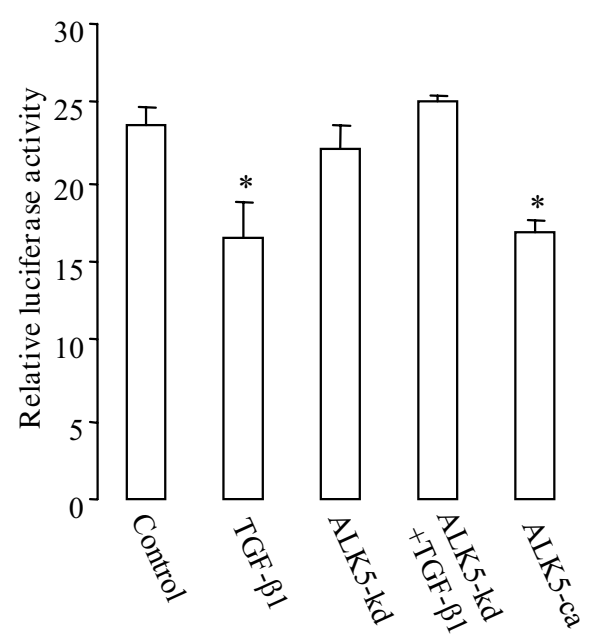

\section{Figure 2}

TGF- $\beta$ I acts through T $\beta$ RII and ALK5 to inhibit aromatase transcription. A) Cells were transfected with Arom -7I4 construct, the control vector PCMV5 or dominant negative T $\beta$ RII. At $24 \mathrm{~h}$ after transfection, they were treated with the control medium or TGF- $\beta$ I (I ng/ml). B) Cells were transfected with Arom -7/4 construct, control vector PCMV5, the dominant negative ALK5 (ALK5-kd) and the constitutively active ALK5 (ALK5-ca). A $\beta$-galactosidase expression vector $(0.5 \mu \mathrm{g})$ was simultaneously co-transfected into cells for normalizing transfection efficiency.

pletely reversed the effect of TGF- $\beta 1$ on aromatase transcription (Fig. 3D).

\section{TGF- $\beta$ I decreased aromatase mRNA stability}

Since the decrease in aromatase mRNA levels could also be due to a decrease in its stability, we tested if TGF- $\beta 1$ regulated aromatase mRNA degradation. Cells were treated with a transcription inhibitor actinomycin $\mathrm{D}$ and the decay of aromatase mRNA was measured from 6 to $48 \mathrm{~h}$. At all time points tested, aromatase mRNA levels were sig- 
A.

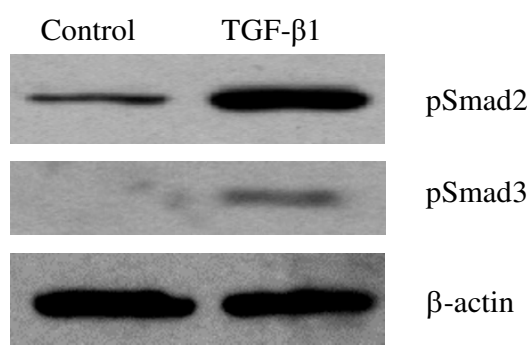

B.

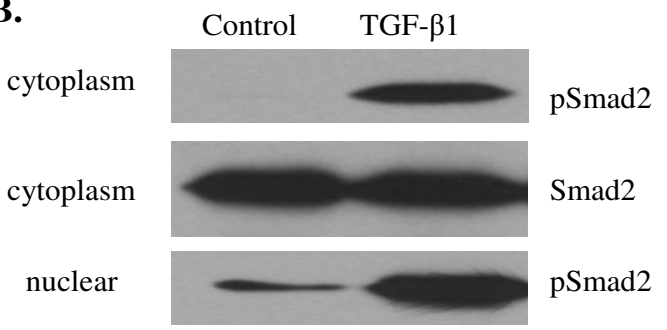

C.

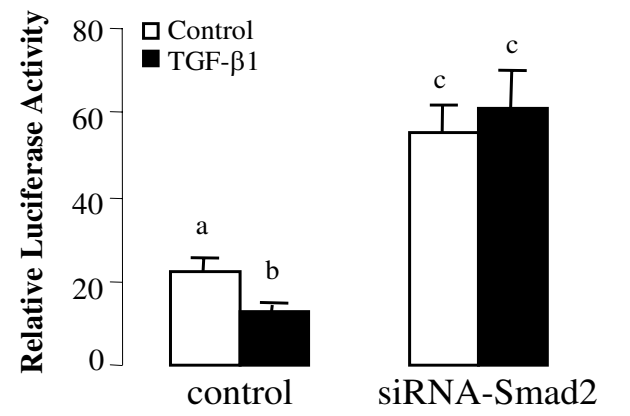

Smad2

$\beta$-actin
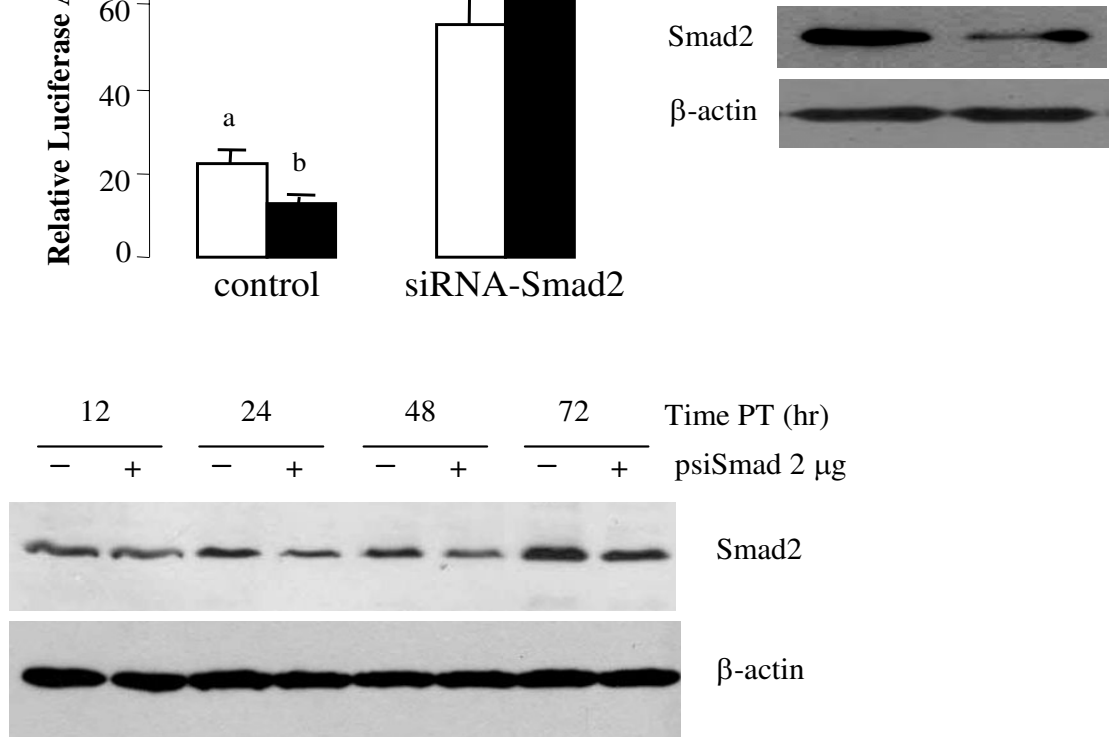

\section{Figure 3}

Smad 2 is involved in TGF- $\beta$ I-inhibited aromatase transcription. A) TGF- $\beta$ I induced Smad 2 phosphorylation. Cells were treated with TGF- $\beta$ I $(\mathrm{I} \mathrm{ng} / \mathrm{ml})$ for I $\mathrm{h}$ and Smad2 and Smad3 phosphorylation was determined by Western blot analysis using specific antibodies. $\beta$-actin was used for the loading control. B) TGF- $\beta$ I induced Smad2 nuclear translocation. Cells were treated with TGF- $\beta$ I as above and cytoplamic and nuclear proteins were analyzed for the phosphorylated Smad2 levels. C) Validation of Smad2 siRNA. Cells were transfected with $2 \mu \mathrm{g}$ of pSuper empty vector or Smad2 siRNA (siSmad2) cloned in pSuper. At various time points after transfection, cell lysates were prepared and probed for Smad2. D) Smad2 siRNA reversed the TGF- $\beta$ I-inhibited aromatase transcription. Cells were transfected with pSuper or pSuper carrying Smad2 siRNA. Smad2 siRNA blocked the effect of TGF- $\beta$ I on aromatase transcription. Knockdown of Smad2 by its siRNA was confirmed by Western blotting. 
A.

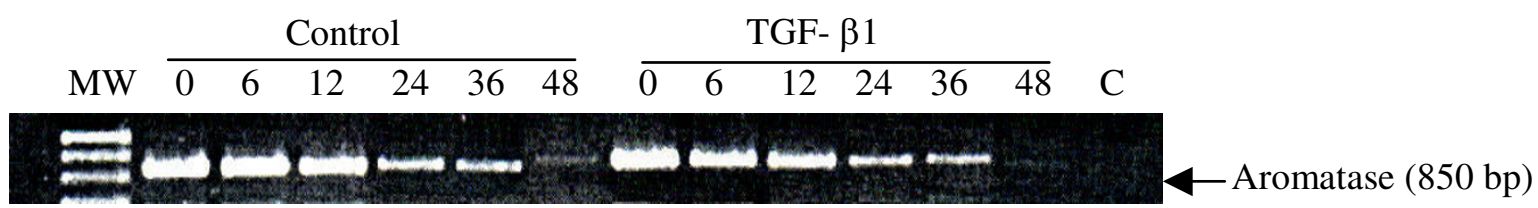

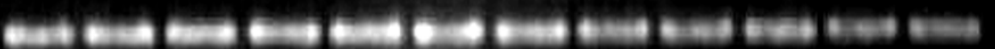
$\longleftarrow$ GAPDH (142 bp)

B.

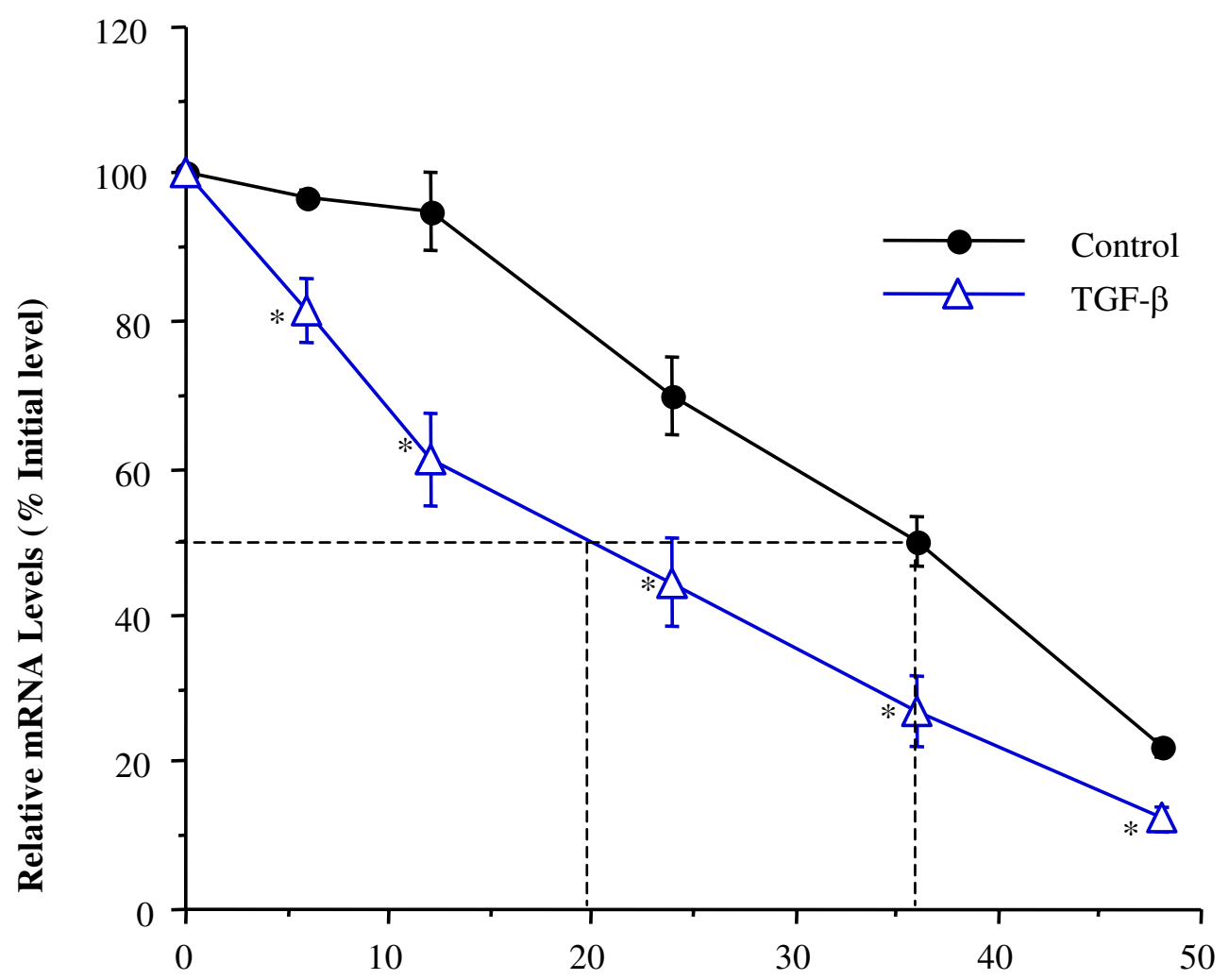

Time of Treatment (hour)

\section{Figure 4}

TGF- $\beta$ I decreased aromatase mRNA stability. Cells seated in 24 -well plates were treated with $2 \mu \mathrm{g} / \mathrm{ml}$ actinomycin D alone or in combination with TGF- $\beta$ I (I ng/ml). Cells were harvested at time 0 (pretreatment), 6, I2, 24, 36 and $48 \mathrm{~h}$ after treatment with TGF- $\beta$ I. Aromatase mRNA levels were determined by semi-quantitative PCR. A) Representative results from one experiment. B) The half-life $\left(T_{1 / 2}\right)$ of aromatase transcript is defined as the time required for aromatse mRNA levels to drop to $50 \%$ of its starting values ( 0 time point). In this study, the $T_{1 / 2}$ value of aromatse mRNA was reduced from $36 \mathrm{~h}$ in the control to $20 \mathrm{~h}$ in the treatment groups with TGF- $\beta$ I. Data are mean \pm SEM of three experiments. $*, P<0.05$ verse the time matched control. 


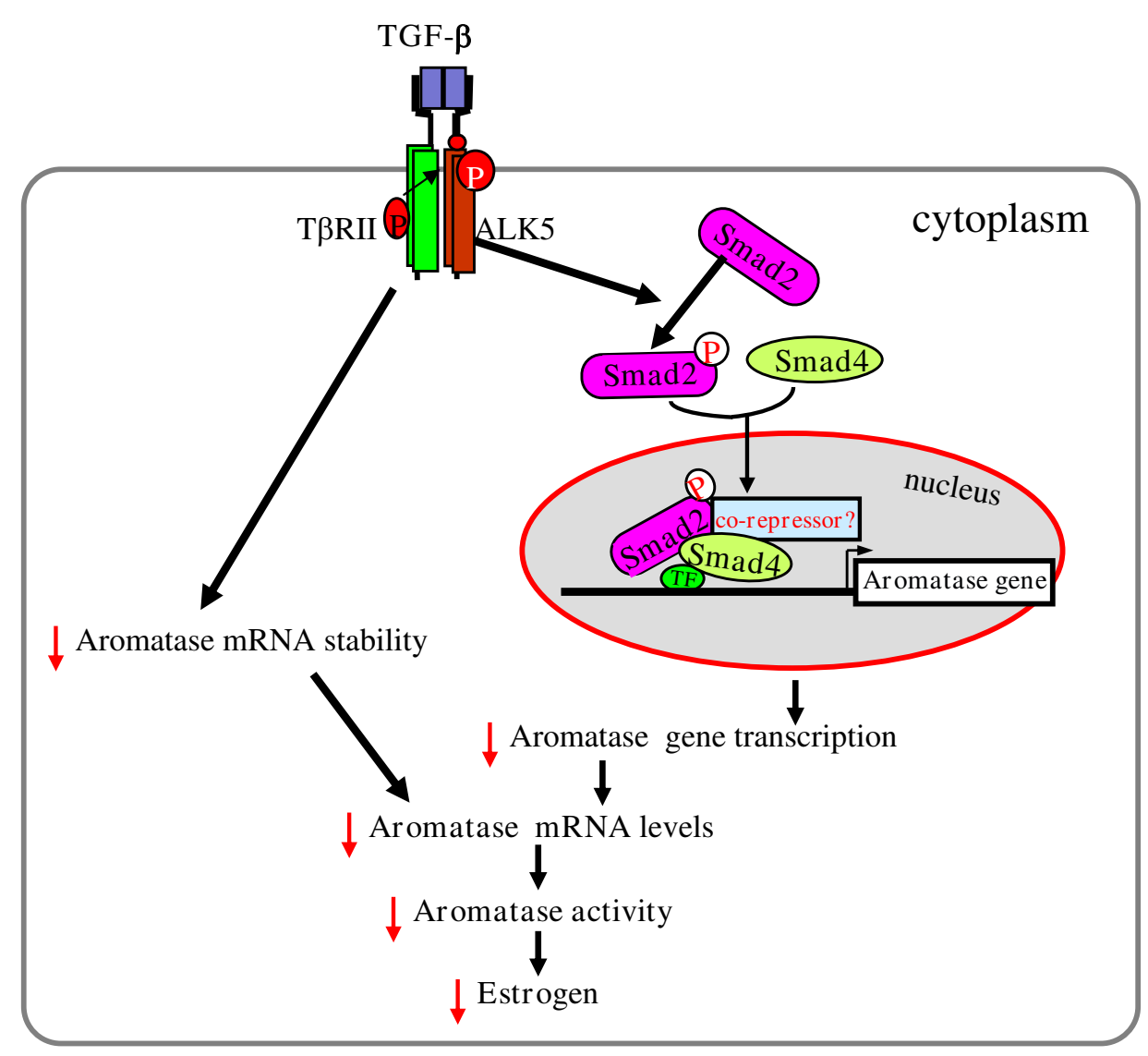

\section{Figure 5}

Proposed model of TGF- $\beta$ action in estrogen production in trophoblast cells. TGF- $\beta$ binds to its serine/threonine receptor complex (T $\beta$ RII and ALK5) to activate Smad2. The phosphorylated Smad2 forms a complex with Smad4 and translocate to the nucleus, where the complex could interact with other transcription factors (TF) and co-repressors to inhibit aromatase gene transcription. TGF- $\beta$ also decreases aromatase mRNA stability, which contributes to a decrease in aromatase mRNA levels. The decrease in aromatase mRNA may lead to a decrease in aromatase activity and thus estrogen biosynthesis in trophoblast cells.

nificantly lower in TGF- $\beta 1$-treated cells than in the control cells (Fig. 4). The half-life of aromatase transcript was approximately $36 \mathrm{~h}$ and $20 \mathrm{~h}$, respectively, in the control and TGF- $\beta 1$-treated cells (Fig. 4B), suggesting that TGF- $\beta 1$ decreased the half-life of aromatase mRNA by $16 \mathrm{~h}$.

\section{Discussion}

Aromatase plays important roles during pregnancy as it is the key enzyme involved in estrogen production. TGF- $\beta$ has been reported to regulate placental development and functions, including estrogen synthesis. In this study, we demonstrated that TGF- $\beta 1$ inhibits aromatase transcription and decreases aromatase mRNA stability, thus providing new insights into the molecular mechanisms underlying the effect of TGF- $\beta 1$ in placental steroidogenesis.

Using luciferase reporter assays, we found that TGF- $\beta 1$ inhibited promoter activity of aromatase gene. Deletion analysis showed that removal of nucleotides between 422 to -117 resulted in a loss of response to TGF- $\beta 1$, as well as the basal promoter activity. This finding suggests that the TGF- $\beta$ response element resides in the region between -117 and -422 . Since there are two overlapping SBEs located at -114 to -118 and -118 to -122 , it is possible that these SBEs are important in mediating the effect of TGF- $\beta 1$ on aromatase transcription. Additional SBEs found in +93 to +97 and -1186 to -1182 may not participate in TGF- $\beta$-regulated aromatase transcription. Our 
finding that -117 to -422 region is important for maintaining the basal promoter activity is consistent with previous studies which showed that constructs containing up to $-125 \mathrm{bp}$ of the placenta aromatase promoter had no transcriptional activity $[29,30]$.

TGF- $\beta$ signals through a receptor complex containing type I and type II serine/threonine kinases. It binds to type II receptors which in turn recruit and phosphorylate type I receptors, resulting the activation of type I receptors. Several type I receptors have been reported to mediate TGF- $\beta$ signaling, including ALK1 and ALK5 [11]. While ALK5 is expressed in a variety of cells, ALK1 expression is restricted to endothelial cells [11]. In this study, we found that the dominant negative mutant of T $\beta$ RII and ALK5 completely reversed the inhibitory effect of TGF- $\beta 1$ on aromatase transcription while constitutively ALK5 mimicked the effect of TGF- $\beta 1$. These results indicate that TGF- $\beta 1$ acts through TBRII and ALK5 to regulate aromatase expression. ALK5 is known to activate the $\operatorname{Smad} 2 / 3$ pathway $[9,11]$. Consistent with this, we found that TGF- $\beta 1$ induced Smad2 phosphorylation and nuclear accumulation in JEG3 cells. Silencing of Smad2 expression using siRNA resulted in the loss of TGF- $\beta 1$ inhibitory effect on aromatase transcription, demonstrating that Smad 2 mediates the effect of TGF- $\beta 1$ on these cells. TGF- $\beta 1$ also activated Smad3; however, since Smad3 expression is very low in JEG3 cells, it is unlikely that it plays a role in TGF- $\beta 1$-regulated aromatase promoter activity.

In addition to regulating aromatase transcription, TGF- $\beta 1$ also decreased aromatase mRNA stability since we found that in the presence of actinomycin D, TGF- $\beta 1$ was able to reduce aromatase mRNA levels by shortening its half-life. The mechanism whereby TGF- $\beta 1$ reduces aromatase mRNA stability is unclear at present. Recently, it was reported that the tissue specific alternative exon I of the aromatase gene play an important role in the posttranscriptional regulation of aromatase gene expression [31]. Whether or not the TGF- $\beta 1$ pathway can target the placental specific exon I.1 to regulate aromatase mRNA stability remains to be determined.

\section{Conclusion}

In summary, we have shown that TGF- $\beta 1$ exerts its regulatory effects on aroamtase mRNA expression at both transcriptional and post-transcriptional levels. TGF- $\beta 1$ acts through the canonical TGF- $\beta$ signaling pathway involving TRRII, ALK5, and Smad2 to inhibit aromatase transcription and through unknown mechanisms to decrease aroamtase mRNA stability. This could in turn decrease aromatase activity, leading to inhibition of estrogen biosynthesis (Fig. 5). These findings further support the role of TGF- $\beta 1$ in regulating human placental functions and pregnancy.

\section{Competing interests}

The authors declare that they have no competing interests.

\section{Authors' contributions}

$\mathrm{HZ}$ carried out the aromatase promoter studies and participated in the design of the study and in manuscript writing. GF conducted the Smad2 siRNA study, repeated many of the luciferase assays and participated in drafting the manuscript. HY performed the aromatase mRNA stability study. CP conceived of the study, participated in its design, and drafted the manuscript. All authors read and approved the final manuscript.

\section{Acknowledgements}

This study was supported by CIHR grants (MOP-53I74 and MOP-8I370) and a Premier's Research Excellent Award to CP. CP is a recipient of a midcareer award from OWHC/CIHR.

\section{References}

I. Knight PG, Glister C: TGF-beta superfamily members and ovarian follicle development. Reproduction 2006, I32(2): 19|-206.

2. Peng C: The TGF-beta superfamily and its roles in the human ovary and placenta. J Obstet Gynaecol Can 2003, 25( I 0):834-844.

3. Jones RL, Stoikos C, Findlay JK, Salamonsen LA: TGF-beta superfamily expression and actions in the endometrium and placenta. Reproduction 2006, I32(2):217-232.

4. Schaffer L, Scheid A, Spielmann P, Breymann C, Zimmermann R, Meuli M, Gassmann M, Marti HH, Wenger RH: Oxygen-regulated expression of TGF-beta 3, a growth factor involved in trophoblast differentiation. Placenta 2003, 24( I 0):94I-950.

5. Luo S, Yu H, Wu D, Peng C: Transforming growth factor-betal inhibits steroidogenesis in human trophoblast cells. Mol Hum Reprod 2002, 8(4):318-325.

6. Chakraborty C, Gleeson LM, McKinnon T, Lala PK: Regulation of human trophoblast migration and invasiveness. Can J Physiol Pharmacol 2002, 80(2): I| |6-124.

7. Caniggia I, Grisaru-Gravnosky S, Kuliszewsky M, Post M, Lye SJ: Inhibition of TGF-beta 3 restores the invasive capability of extravillous trophoblasts in preeclamptic pregnancies. J Clin Invest 1999, I03(12): |64|-1650.

8. Morrish DW, Bhardwaj D, Paras MT: Transforming growth factor beta I inhibits placental differentiation and human chorionic gonadotropin and human placental lactogen secretion. Endocrinology I99I, I29(I):22-26.

9. Attisano L, Wrana JL: Signal transduction by the TGF-beta superfamily. Science 2002, 296(5573): I646-1647.

10. Derynck R, Feng XH: TGF-beta receptor signaling. Biochim Biophys Acta 1997, I 333(2):FI05-I50.

II. Graham H, Peng C: Activin receptor-like kinases: structure, function and clinical implications. Endocr Metab Immune Disord Drug Targets 2006, 6(I):45-58.

12. ten Dijke P, Miyazono K, Heldin $\mathrm{CH}$ : Signaling inputs converge on nuclear effectors in TGF-beta signaling. Trends Biochem Sci 2000, 25(2):64-70.

13. Massague ], Gomis RR: The logic of TGFbeta signaling. FEBS Lett 2006, 580( I 2):28I I-2820.

14. Massague J, Seoane J, Wotton D: Smad transcription factors. Genes Dev 2005, I 9(23):2783-28I0.

15. Simpson ER, Clyne C, Rubin G, Boon WC, Robertson K, Britt K, Speed C, Jones M: Aromatase--a brief overview. Annu Rev Physiol 2002, 64:93-127.

16. Simpson ER: Aromatase: biologic relevance of tissue-specific expression. Semin Reprod Med 2004, 22(1): I I-23.

17. Mendelson CR, Kamat A: Mechanisms in the regulation of aromatase in developing ovary and placenta. J Steroid Biochem $\mathrm{Mol}$ Biol 2007, I 06( I-5):62-70.

18. Song Y, Keelan J, France JT: Activin-A stimulates, while transforming growth factor beta I inhibits, chorionic gonado- 
trophin production and aromatase activity in cultured human placental trophoblasts. Placenta 1996, I7(8):603-610.

19. Rainey WE, Price TM, Means GD, Carr BR: Effect of type I transforming growth factor-beta on the level of aromatase cytochrome P-450 in human fetal hepatocytes. J Endocrinol 1992, I33(2):3| I-320.

20. Simpson ER, Merrill JC, Hollub AJ, Graham-Lorence S, Mendelson CR: Regulation of estrogen biosynthesis by human adipose cells. Endocr Rev 1989, I0(2): I36-148.

21. Emoto N, Ling N, Baird A: Growth factor-mediated regulation of aromatase activity in human skin fibroblasts. Proc Soc Exp Biol Med I99I, 196(3):35I-358

22. Shozu M, Zhao Y, Simpson ER: TGF-betal stimulates expression of the aromatase (CYPI9) gene in human osteoblast-like cells and THP-I cells. Mol Cell Endocrinol 2000, I60(I-2):I23-I33.

23. Fiorelli G, Frediani U, Martineti V, Franchi A, Gori F, Franceschelli F, Tanini A, Serio M, Brandi ML: Aromatase expression and activity in the human leukaemic cell line FLG 29.I. J Steroid Biochem Mol Biol 1998, 66(3): 105-II2.

24. Xu G, Zhong Y, Munir S, Yang BB, Tsang BK, Peng C: Nodal induces apoptosis and inhibits proliferation in human epithelial ovarian cancer cells via activin receptor-like kinase 7. J Clin Endocrinol Metab 2004, 89(I I):5523-5534.

25. Major MB, Jones DA: Identification of a gadd45beta 3' enhancer that mediates SMAD3- and SMAD4-dependent transcriptional induction by transforming growth factor beta. J Biol Chem 2004, 279(7):5278-5287.

26. Munir S, Xu G, Wu Y, Yang B, Lala PK, Peng C: Nodal and ALK7 inhibit proliferation and induce apoptosis in human trophoblast cells. J Biol Chem 2004, 279(30):3 |277-3 I 286.

27. Andres JL, DeFalcis D, Noda M, Massague J: Binding of two growth factor families to separate domains of the proteoglycan betaglycan. J Biol Chem 1992, 267(9):5927-5930.

28. Wu D, Luo S, Wang $Y$, Zhuang $L$, Chen $Y$, Peng $C$ : Smads in human trophoblast cells: expression, regulation and role in TGFbeta-induced transcriptional activity. Mol Cell Endocrinol 200I, I 75(I-2): || ||-|2|.

29. Kamat A, Alcorn JL, Kunczt C, Mendelson CR: Characterization of the regulatory regions of the human aromatase (P450arom) gene involved in placenta-specific expression. Mol Endocrinol 1998, I 2(II): 1764-1777.

30. Sun T, Zhao Y, Mangelsdorf DJ, Simpson ER: Characterization of a region upstream of exon I.I of the human CYPI9 (aromatase) gene that mediates regulation by retinoids in human choriocarcinoma cells. Endocrinology 1998 |39(4):|684-|69|.

31. Wang H, Li R, Hu Y: The alternative noncoding exons I of aromatase (Cyp I9) gene modulate gene expression in a posttranscriptional manner. Endocrinology 2009, I 50(7):330I-3307.
Publish with Biomed Central and every scientist can read your work free of charge

"BioMed Central will be the most significant development for disseminating the results of biomedical research in our lifetime. "

Sir Paul Nurse, Cancer Research UK

Your research papers will be:

- available free of charge to the entire biomedical community

- peer reviewed and published immediately upon acceptance

- cited in PubMed and archived on PubMed Central

- yours - you keep the copyright
BioMedcentral 